\title{
GAMBARAN KEMATIAN IBU DI KABUPATEN MAJALENGKA TAHUN 2015 (STUDY KUALITATIF)
}

\author{
Ruri Yuni Astari ${ }^{1}$, Debby Sandela ${ }^{2}$, Gita Elvira ${ }^{3}$ \\ 1,2,3 STIKes YPIB Majalengka, ruriyuniastari@stikesypib.ac.id
}

\begin{tabular}{l} 
INFO ARTIKEL \\
\hline Riwayat Artikel: \\
Diterima: 11-01-2018 \\
Disetujui: 30-01-2018 \\
\\
Kata Kunci: \\
Kematian Ibu Dari Faktor \\
Determinan Jauh Antara \\
Dan Dekat, Hambatan \\
Dan Masalah Rujukan, \\
Akses Pelayanan \\
Kesehatan
\end{tabular}

Kesehatan

\begin{abstract}
ABSTRAK
Abstrak: Kematian ibu di Kabupaten Majalengka termasuk dalam peringkat 16 (atau peringkat 10 terbawah) dari 27 kabupaten/ kota yang ada di Propinsi Jawa Barat tahun 2015. Penelitian ini bertujuan untuk mengetahui gambaran kematian ibu di Kabupaten Majalengka Tahun 2015. Metode penelitian yang digunakan metode kualitatif melalui pendekatan studi naratif. Populasi penelitian ibu yang meninggal dunia saat hamil, bersalin, dan nifas di Wilayah Puskesmas Kabupaten Majalengka Tahun 2015 sebanyak 20 orang, dan yang dijadikan partisipan berjumlah 13 orang. Instrumen penelitian menggunakan kuesioner yang di adopsi dari hasil penelitian Febriana Prodi Magister Epidemiologi Program Pasca Sarjana Undip Tahun 2007 serta dokumen autopsi verbal kematian maternal dan perinatal. Pengambilan data melalui wawancara dan dokumentasi. Analisis data secara kualitatif melalui tahapan reduksi data, penyajian data dan penarikan kesimpulan. Hasil penelitian lebih dari setengahnya ibu meninggal pada periode nifas penyebab tertinggi kematian ibu karena Hipertensi Dalam Kehamilan (HDK). Faktor determinan jauh : lebih dari setengahnya pendidikan ibu SMP, sebagian besar tidak bekerja dan rata-rata pendapatan keluarga sesuai dengan UMR Kabupaten Majalengka. Faktor determinan antara : sebagian besar ibu tidak mengalami KEK dan anemia, usia ibu meninggal pada usia 20-35 tahun, lebih dari setengahnya terjadi pada primipara, jangkauan pelayanan kesehatan dari lama rujukan sampai tiba di pelayanan kesehatan ditempuh sekitar 1-2 jam dan hampir seluruh ibu melakukan pemeriksaan kehamilan sampai persalinan dengan tenaga kesehatan. Faktor determinan dekat yang berpengaruh terhadap kematian ibu adalah komplikasi pada kehamilan, persalinan dan nifas. Hambatan dan masalah rujukan pada ibu yang meninggal dikarenakan keluarga terlambat merujuk ibu ke fasilitas kesehatan, jarak yang jauh dari fasilitas kesehatan, akses BPJS serta masalah transportasi yang lama menunggu. Akses pelayanan kesehatan jarak tempuh paling jauh $\pm 15 \mathrm{Km}$ dan paling dekat $+1 \mathrm{Km}$. Kecepatan dan ketepatan tenaga kesehatan (baik bidan maupun dokter) dalam mengambil keputusan, merujuk, melakukan penanganan tindakan kegawatdaruratan serta stabilisasi kondisi pasien merupakan faktor penting dalam menyelamatkan nyawa ibu, karena kematian ibu sering terjadi karena keterlambatan dalam penentuan diagnosa komplikasi, terlambat mengambil keputusan, terlambat merujuk dan terlambat ditangani.
\end{abstract}

Abstract: Maternal mortality in Majalengka District was in the $16^{\text {th }}$ ranking (or the 10 th lowest) of 27 districts/cities in West Java Province by 2015. This study aims to determine the description of maternal mortality in Majalengka District in 2015. The study method used was qualitative method through narrative study approach. The populations of the study were mothers who died during pregnancy, childbirth, and postpartum in the work area of Public Health Centers in District Majalengka in 2015 as many as 20 people, and the participants were 13 people. The study instrument used questionnaire which was adopted from the study result of Febriana, Epidemiology Master Study Program of Postgraduate Program of Diponegoro University in 2007 and document of verbal autopsy of maternal and perinatal mortality. Data collection was performed through observation, interview and documentation. Qualitative data analysis was conducted through the stages of data reduction, data presentation and conclusion. The results of this study showed that more than half of mothers died during the postpartum period with the highest cause of maternal mortality due to Hypertension In Pregnancy (PIH), the distant determinant factors were: more than half had junior high school education, most of them were unemployed and the average family income was in accordance with Minimum Wage in Majalengka District; the intermediate determinant factors were: most of the mothers did not experience Chronic Energy Deficiency (CED) and anemia, the women died at the age of 20-35 years, more than half deaths occurred in primiparous, health service coverage from referral duration until arrived at health service took about 1-2 hours and almost all mothers did prenatal care until delivery with health personel; the outcome determinant factors affecting maternal mortality were complications during pregnancy, childbirth and postpartum. The referral obstacles and problems in women who died were due to the family performed late referral to health facilities, long distance from health facilities, access to health insurance (BPJS) and long time in waiting transportation. The longest distance of health service access was $+15 \mathrm{Km}$ and the closest was +1 $\mathrm{Km}$. The speed and accuracy of health workers (both midwives and doctors) in making decision, referral, performing emergency measures and stabilizing the condition of the patient were important factors in saving the lives of mothers, because maternal mortality often occurs due to delay in the determination of complication diagnosis, delay in making decision, delay in performing referral and delay in receiving care. 


\section{A. LATAR BELAKANG}

Kematian ibu menurut WHO adalah kematian yang terjadi saat hamil, bersalin, atau dalam 42 hari pasca persalinan dengan penyebab yang berhubungan langsung atau tidak langsung terhadap kehamilan. Pengurangan kematian ibu sudah lama menjadi prioritas kesehatan global dan menjadi tantangan serta perhatian utama bagi kesehatan masyarakat meskipun banyak strategi yang di rancang oleh lembaga dunia untuk membatasi itu. ${ }^{(1-2)}$ Kematian ibu di seluruh dunia menurut World Health Organization (WHO) diperkirakan sebanyak 289.0oo jiwa per tahun, diantaranya 800 perempuan meninggal setiap harinya akibat komplikasi kehamilan dan proses kelahiran. Sekitar 99\% dari seluruh kematian ibu terjadi di negara berkembang. Sekitar 80\% kematian maternal merupakan akibat meningkatnya komplikasi selama kehamilan, persalinan dan nifas(3) Untuk merespon tantangan ini, The Millenium Development Goal (MDG5) yang bertujuan untuk memperbaiki kesehatan ibu terus dikembangkan diantaranya target untuk mengurangi 3/4 dari MMR (Maternal Mortality Rate) antara tahun 1990-2015 dan mencapai akses universal terhadap perawatan kesehatan reproduksi pada tahun $2015^{(1)}$

Ditinjau dari HDI (Human Development Index), Indonesia menduduki ranking 110 dari 187 pada tahun 2015 mengalami peningkatan dari tahun sebelumnya tetapi masih jauh tertinggal dari negara-negara ASEAN lainnya seperti Singapura, Brunei, Malaysia dan Thailand(4).Berdasarkan Survey Demografi Kesehatan Indonesia menyebutkan bahwa angka kematian ibu yang berkaitan dengan kehamilan, persalinan, dan nifas menjadi 359 per 100.000 kelahiran hidup pada tahun 2012. Penyebab kematian ibu di Indonesia masih didominasi oleh komplikasi perdarahan (32\%) dan hipertensi dalam kehamilan (25\%), diikuti oleh infeksi (5\%), partus lama (5\%), dan abortus (1\%). selain penyebab obstetrik, kematian ibu juga disebabkan oleh penyebab lain-lain (non obstetrik) sebesar 32\%(5).

Kematian ibu adalah kematian wanita dalam masa kehamilan, persalinan dan dalam masa 42 hari (6 minggu) setelah berakhirnya kehamilan tanpa memandang usia kehamilan maupun tempat melekatnya janin, oleh sebab apapun yang berkaitan dengan atau diperberat oleh kehamilan atau pengelolaannya, bukan akibat kecelakaan ${ }^{(6)}$. Setiap jam, satu perempuan meninggal dunia ketika melahirkan atau karena sebab-sebab yang berhubungan dengan kehamilan(7). Ibu adalah orang tua perempuan dari seorang anak yang merupakan sosok yang luar biasa, namun sangat peka terhadap berbagai masalah kesehatan dan perlu mendapatkan prioritas dalam penyelenggaraan upaya kesehatan. Ibu merupakan kelompok rentan sehingga upaya pemerintah yang nyata perludilakukan untuk meningkatkan derajat kesehatan masyarakat salah satunya difokuskan pada program kesehatan $\mathrm{ibu}^{(8)}$.

masyarakat salah satunya difokuskan pada program kesehatan ibu(8).

Peningkatan kesehatan ibu di Indonesia yang merupakan Tujuan Pembangunan Milenium (MDG) kelima berjalan lambat dalam beberapa tahun terakhir. Rasio kematian ibu yang diperkirakan sekitar 228 per 100.000 kelahiran hidup, tetap tinggi di atas 200 selama dekade terakhir, meskipun telah dilakukan upaya-upaya untuk meningkatkan pelayanan kesehatan ibu padahal target AKI di Indonesia pada tahun 2015 adalah 102 kematian per 100.000 kelahiran hidup(7). Stagnasi ini menuntut berbagai inovasi dan strategi untuk mengatasi ancaman global ini. ${ }^{(1)}$

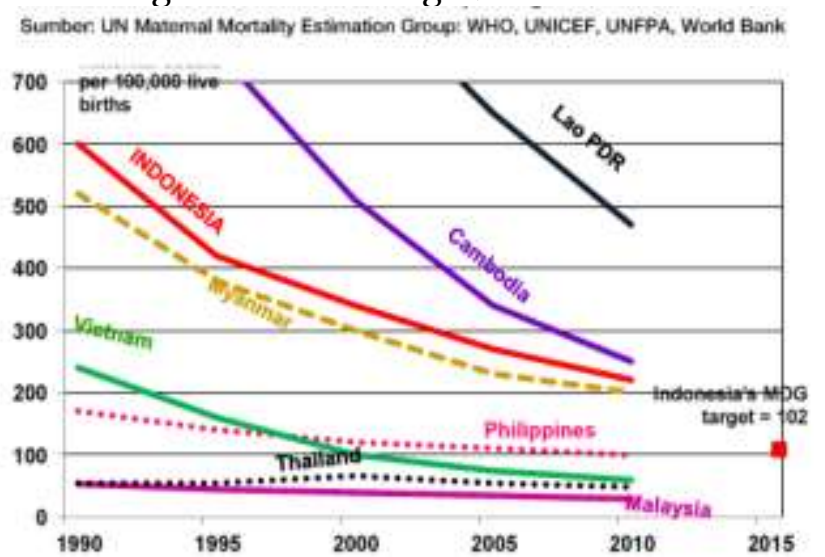

Gambar 1. Tren Kematian Ibu se-ASEN

Sebagai upaya penurunan AKI, pemerintah melalui Kementerian Kesehatan sejak tahun 1990 telah meluncurkan Safe Motherhood Initiative, sebuah program yang memastikan semua wanita mendapatkan perawatan yang dibutuhkan sehingga selamat dan sehat selama kehamilan dan persalinannya. Upaya tersebut dilanjutkan dengan program Gerakan Sayang Ibu/ GSI di tahun 1996 oleh Presiden Republik Indonesia dan program penempatan bidan di tingkat desa secara besarbesaran yang bertujuan untuk mendekatkan akses pelayanan kesehatan ibu dan bayi baru lahir ke masyarakat. Upaya lain yang juga telah dilakukan yaitu strategi Making Pregnancy Safer yang dicanangkan pada tahun 2000. Pada tahun 2012 Kementerian Kesehatan meluncurkan program Expanding Maternal and Neonatal Survival (EMAS) dalam rangka menurunkan angka kematian ibu dan neonatal sebesar 25\%. Program ini dilaksanakan di provinsi dan kabupaten dengan jumlah kematian ibu dan neonatal yang besar, yaitu Sumatera Utara, Banten, Jawa Barat, Jawa Tengah, Jawa Timur, dan Sulawesi Selatan. Dasar pemilihan provinsi tersebut disebabkan 52,6\% dari jumlah total kejadian kematian ibu di Indonesia berasal dari enam provinsi tersebut. Sehingga dengan menurunkan angka kematian ibu di enam provinsi tersebut diharapkan akan dapat 
menurunkan angka kematian ibu di Indonesia secara signifikan $^{(8)}$

Upaya lain yang dilakukan pemerintah untuk menurunkan kematian ibu dan kematian bayi yaitu dengan mendorong agar setiap persalinan ditolong oleh tenaga kesehatan terlatih yaitu dokter spesialis kebidanan dan kandungan (dr. SpOG), dokter umum, dan bidan, serta diupayakan dilakukan di fasilitas pelayanan kesehatan(8-9). Sebagian besar kematian ibu timbul dari komplikasi yang tidak dapat diprediksi atau tidak dapat dicegah, kondisi seperti ini harus selalu dipersiapkan untuk semua perempuan ${ }^{(10)}$. Persalinan di fasilitas kesehatan menjadi krusial untuk tindakan yang efektif pada saat wanita melahirkan. Untuk memastikan kehamilan yang optimal, maka semua wanita membutuhkan akses kehadiran bidan yang trampil dan penyediaan dasar serta perawatan kegawatdaruratan kebidanan(9), karena hal ini dapat mencegah hingga $33 \%$ kematian ibu(11). Pengiriman di fasilitas kesehatan dapat meningkatkan ketrampilan petugas kesehatan dengan lingkungan yang kondusif, perlengkapan dan peralatan yang memadai serta rujukan yang adekuat $^{(1)}$.

Angka kematian ibu di Provinsi Jawa Barat tahun 2015 sebesar 86 per 100.00o kelahiran hidup dengan jumlah kematian sebanyak 843 kasus. Penyebab terbesar kematian ibu akibat perdarahan (27,1\%), hipertensi $(26,3 \%)$, infeksi $(4,8 \%)$, partus lama (1,3\%), dan faktor lainnya (40,4\%). Kematian tertinggi berada di Kabupaten Bogor sebanyak 69 orang, posisi kedua diduduki Kabupaten Karawang dengan 68 kasus, Kabupaten Indramayu dan Tasikmalaya 55 kasus, Kabupaten Sukabumi 54 kasus, Kabupaten Cirebon 53 kasus, Kabupaten Cianjur 49 kasus, Kabupaten Garut 45 kasus, Bandung Barat 40 kasus, Bandung 38 kasus, dan Bekasi 36 kasus $^{(12)}$.

Kematian ibu di Kabupaten Majalengka termasuk dalam peringkat 16 (atau peringkat 10 terbawah)dari 27 kabupaten/ kota yang ada di Propinsi Jawa Barat Tahun 2015. Jumlah kematian ibu pada tahun 2014 berjumlah 21 dari 21300 orang (0,098\%) menurun 0,005\% pada tahun 2015 berjumlah 20 dari 21427 orang (o,093\%). Kematian ibu menurut penyebab diantaranya hipertensi dalam kehamilan 9 orang (45\%), perdarahan 6 orang (30\%), penyakit jantung 2 orang (10\%), infeksi 1 orang (5\%), hipokalemia 1 orang (5\%), dan post SC 1 orang (5\%). Kematian ibu menurut waktu terjadinya kematian ibu hamil 5 orang (25\%), ibu melahirkan 6 orang (30\%), dan ibu nifas 9 orang (45\%). Kematian tertinggi di Kabupaten Majalengka terbanyak di UPTD Puskesmas Kertajati terdapat 4 orang, 2 orang saat hamil, dan 2 orang saat bersalin ${ }^{(13)}$.

Berdasarkan pemetaan awal dari data kematian ibu puskesmas di Kabupaten Majalengka tahun
2015 dari 20 kasus kematian ibu sebagian besar proporsi kematian berada di Puskesmas wilayah utara Kabupaten Majalengka sebanyak 10 orang (50,0\%) meliputi Puskesmas Sukamulya, Kertajati, Balida, Loji dan Jatiwangi, di wilayah timur sebanyak 5 orang $(25,0 \%)$ berada di Puskesmas Cigasong, Salagedang, Sindang, Sumberjaya dan Waringin, di wilayah selatan sebanyak 5 orang (25,0\%) meliputi Puskesmas Margajaya, Malausma, Argapura, dan Maja, sedangkan tidak terdapat di Puskesmas wilayah barat Kabupaten Majalengka.Tingginya angka kematian ibu ataupun bayi hampir rata-rata lebih disebabkan oleh lambatnya penanganan kelahiran, karena keluarga pasien kerap lambat melakukan pelaporan terhadap petugas kesehatan atau bidan setempat untuk di rujuk ke rumah sakit(13).

Hasil penelitian Sarwani dan Nurlaela (2010) mengenai Analisis Faktor Risiko Kematian Ibu (Studi Kasus di Kabupaten Banyumas) terhadap 102 responden diperoleh faktor komplikasi perdarahan $(42,2 \%)$, riwayat penyakit $(25,5 \%)$, riwayat kelainan persalinan $(49,0 \%)$, pemeriksaan kehamilan tidak lengkap (12,7\%), umur risiko $<20$ dan 35 tahun $(22,5 \%)$ dan paritas risiko $>4$ $(26,5 \%)^{(14)}$. Sedangkan hasil penelitian Aeni (2011) mengenai Faktor Risiko Kematian Ibu di Kabupaten Pati berdasarkan penyebab tertinggi akibat penyakit jantung (33,1\%), berdasarkan waktu terjadinya tertinggi pada komplikasi kehamilan (70,8\%) dibandingkan persalinan (50,0\%) dan nifas (41,7\%), berdasarkan determinan usia berisiko $(37,5 \%)$, dan paritas risiko $(41,7 \%)^{(15)}$.

Penyebab tingginya kematian ibu dari penyebab langsung kematian ibu yaitu trias klasik berupa perdarahan, infeksi, dan gestosis atau keracunan kehamilan. Disamping itu masih ada faktor lain yang juga cukup penting yaitu pemberdayaan perempuan yang kurang baik, latar belakang pendidikan, sosial ekonomi keluarga, lingkungan masyarakat dan politik serta kebijakan juga berpengaruh $^{(16)}$. Faktor- faktor ini akan memengaruhi kondisi ibu hamil, bersalin dan nifassehingga menyebabkan kondisi yang lebih parah, komplikasi yang tidak terdeteksi dengan baik dan penanganan yang tidak adekuat ${ }^{(17)}$. Maka dari itu pemerintah bersama masyarakat bertanggung jawab untuk menjamin bahwa setiap ibu memiliki akses terhadap pelayanan kesehatan ibu yang berkualitas, mulai dari saat hamil, pertolongan persalinan oleh tenaga kesehatan terlatih dan perawatan pasca persalinan bagi ibu dan bayi, perawatan khusus dan rujukan jika terjadi komplikasi serta akses terhadap keluarga berencana. ${ }^{(18)}$ 


\section{B. METODE PENELITIAN}

Metode penelitian yang digunakan metode kualitatif melalui pendekatan studi naratif. Populasi penelitian yaitu ibu yang meninggal dunia saat hamil, bersalin, dan nifas di Wilayah Puskesmas Kabupaten Majalengka Tahun 2015 sebanyak 20 orang, dan yang dijadikan partisipan berjumlah 13 orang. Instrumen penelitian menggunakan kuesioner yang di adopsi dari hasil penelitian Febriana mengenai Faktor-Faktor Risiko Yang Mempengaruhi Kematian Maternal, Prodi Magister Epidemiologi Program Pasca Sarjana Undip Tahun $2007^{(19)}$ serta dokumen autopsi verbal kematian maternal dan perinatal. Pengambilan data melalui observasi, wawancara (interview), dan dokumentasi. Analisis data secara kualitatif melalui tahapan reduksi data, penyajian data dan penarikan kesimpulan.

\section{HASIL DAN PEMBAHASAN}

\section{Karakteristik Kematian Ibu di Kabupaten Majalengka}

Berdasarkan karakteristik kematian ibu, lebih dari setengahnya ibu meninggal periode nifas sejumlah 8 orang $(61,5 \%)$ dan periode persalinan sejumlah 5 orang $(38,5 \%)$. Periode nifas dengan penyebab tertinggi kematian ibu karena Hipertensi Dalam Kehamilan (HDK). Dari data tahun 20122015 48\% penyebab AKI di Kabupaten Majalengka adalah HDK. Trend ini bergeser dari penyebab sebelumnya karena perdarahan, sekarang HDK menjadi penyumbang posisi pertama AKI di Kabupaten Majalengka. ${ }^{13}$ Hasil ini sesuai dengan data dari Bina Gizi Kesehatan Ibu dan Anak Kementerian Kesehatan RI tahun 2013 dimana Kematian ibu melahirkan akibat hipertensi mencapai 30 persen dan sekarang menempati yang tertinggi. Wilayah angka kematian ibu tertinggi di wilayah utara Kabupaten Majalengka yaitu di Puskesmas Kertajati, Balida dan Jatiwangi.

\section{Faktor Determinan Jauh}

Faktor determinan jauh, lebih dari setengahnya pendidikan ibu SMP sebesar 54\%, sebagian besar tidak bekerja sebesar $77 \%$ dan rata-rata pendapatan keluarga Rp 1.576.923. Data di Kabupaten Majalengka menunjukkan bahwa rata-rata masyarakat berpendidikan SD atau SMP sehingga akan berpengaruh terhadap pengetahuan dan penghasilan yang di dapat di dalam keluarga. ${ }^{20}$ Walaupun pendapatan keluarga rata-rata $\mathrm{Rp}$ 1.576.923 dan ini mendekati dengan UMR (Upah Minimum Regional) Kabupaten Majalengka Rp 1.525.632,00 21 tetapi dengan kebutuhan hidup sekarang ini yang semakin naik membuat ada sebagian ibu hamil yang terpaksa bekerja untuk mencari tambahan penghasilan keluarga.
Hasil penelitian ini sejalan dengan penelitian Sumarni bahwa pekerjaan mempunyai hubungan dengan kematian ibu dengan nilai $\mathrm{p}=0,019$, dalam penelitian ini sebagian besar kematian ibu terjadi pada ibu rumah tangga. Hal ini dimungkinkan karena pada ibu rumah tangga disibukkan dengan urusan domestik rumah tangga akan mempunyai waktu yang relatif sedikit untuk mendapatkan informasi yang memadai tentang kesehatannya. Hal tersebut juga terkait dengan keadaan ekonomi keluarga dan pengetahuan ibu yang kurang. Ibu yang bekerja sebagai ibu rumah tangga secara ekonomi sangat tergantung pada pendapatan suaminya dan tidak mempunyai pendapatan yang lebih yang bisa digunakan untuk memperoleh kebutuhan selama hamil, melahirkan dan masa nifas. ${ }^{17}$

\section{Faktor Determinan Antara}

Faktor determinan antara, sebagian besar ibu tidak mengalami KEK dan anemia (hanya satu partisipan saja yang terkena KEK dan anemia), usia ibu meninggal pada usia aman untuk hamil 20-35 tahun, lebih dari setengahnya terjadi pada primipara, jangkauan pelayanan kesehatan dari lama rujukan sampai tiba di pelayanan kesehatan ditempuh sekitar 1-2 jam dan hampir seluruh ibu melakukan pemeriksaan kehamilan sampai persalinan dengan tenaga kesehatan. Ini artinya dari kesadaran serta pengetahuan ibu sudah baik mengenai pentingnya kesehatan terutama menjaga kehamilan untuk ibu dan janinnya. Tetapi risiko yang timbul dalam kehamilan bersifat dinamis, karena ibu hamil yang pada mulanya normal secara tiba-tiba dapat menjadi berisiko tinggi. Pengawasan pemberian asuhan antenatal care yang baik akan menjadi salah satu tiang penyangga program safe motherhood dalam usaha menurunkan angka kesakitan dan kematian ibu. Dilihat dari topografinya, Kabupaten Majalengka dibagi dalam tiga zona daerah yaitu daerah pegunungan, daerah bergelombang/berbukit dan daerah dataran rendah dimana jarak dari kecamatan ke kabupaten berkisar antara 0-37 km. Sebagian besar kematian ibu terjadi di daerah utara dan selatan Kabupaten Majalengka, daerah ini termasuk dataran rendah dan pegunungan. Banyak hambatan sehingga akses pelayanan kesehatan menjadi permasalahan pokok pada kematian ibu diantaranya 1) terlambat mencari pertolongan tenaga kesehatan walaupun akses terhadap tenaga kesehatan tersedia 24/7 (24 jam dalam sehari dan 7 hari dalam seminggu) yaitu seperti masalah tradisi/kepercayaan dalam pengambilan keputusan di keluarga, ketidakmampuan menyediakan biaya non medis dan biaya media lainnya seperti obat jenis tertentu golongan darah sampai transportasi, 2) tenaga kesehatan terlambat melakukan pencegahan dan atau mengidentifikasi komplikasi secara dini, 3) keluarga terlambat merujuk karena tidak mengerti 
tanda bahaya yang mengancam jiwa ibu dan 4) tenaga kesehatan tidak mampu mengadvokasi pasien dan keluarganya mengenai pentingnya merujuk tepat waktu untuk menyelamatkan jiwa ibu. ${ }^{21}$ Penelitian yang sejalan di Kabupaten Cilacap, faktor keterlambatan mengambil keputusan untuk merujuk dan keterlambatan mencapai tempat rujukan berhubungan dengan kematian ibu. ${ }^{22}$ Pada penelitian ini, kelompok kasus mengalami lebih dari satu jenis keterlambatan dan yang paling banyak adalah keterlambatan memutuskan dan membawa ibu ke fasilitas kesehatan. Akibat keengganan ibu untuk segera menuju fasilitas kesehatan karena menganggap tanda komplikasi yang dialami biasa terjadi dalam kehamilan, sementara anggota keluarga tidak mengetahui berbagai tanda kegawatan pada komplikasi obstetrik. ${ }^{15}$

\section{Faktor Determinan Dekat}

Determinan dekat yang berpengaruh terhadap kematian ibu adalah komplikasi pada kehamilan, persalinan dan nifas. Komplikasi yang paling banyak adalah disebabkan karena Hipertensi Dalam Kehamilan, dimana semua gejala berawal dari kehamilan yang berlanjut ke persalinan dan nifas sampai ibu mengalami kejang/eklampsi. Hipertensi diperkirakan menjadi komplikasi sekitar 7-10\% seluruh kehamilan. Dari seluruh ibu yang mengalami hipertensi selama hamil, setengah sampai dua pertiganya didiagnosis mengalami preeklampsi atau eklampsi. Beberapa faktor yang berpotensi meningkatkan prevalensi HDK ini adalah kehamilan pertama kali (primigravida) dan pada penelitian ini $53 \%$ terjadi pada primipara. Hipertensi dalam kehamilan adalah hipertensi yang terjadi saat kehamilan berlangsung dan biasanya pada bulan terakhir kehamilan atau lebih setelah 20 minggu usia kehamilan pada wanita yang sebelumnya normotensif, tekanan darah mencapai nilai $140 / 90 \mathrm{mmHg}$, atau kenaikan tekanan sistolik $30 \mathrm{mmHg}$ dan tekanan diastolik $15 \mathrm{mmHg}$ di atas nilai normal.23 Biasanya HDK ini akan bisa mengarah ke pre eklampsi, dimana kriteria yang mendefinisikan pre-eklampsia tidak berubah selama dekade yang lalu, yaitu onset pada usia gestasi $>20$ minggu proteinuria 24 jam $\geq 30 \mathrm{mg} /$ hari atau konsentrasi protein $\geq 30 \mathrm{mg}(\geq 1+$ pada dipstik) minimal dua sampel urin acak, kemudian dikumpulkan 4-6 jam dan tidak lebih dari 7 hari, gejala lainnya adalah tekanan darah sistolik $>140$ $\mathrm{mmHg}$ atau tekanan darah diastolik $\geq 90 \mathrm{mmHg}$ diukur dua kali, dengan manset yang tepat, 4-6 jam dan kurang dari 7 hari terpisah, dan hilangnya semua kelainan ini sebelum akhir minggu ke 6 postpartum. ${ }^{24}$ Penelitian ini sejalan dengan penelitian Febriani menunjukkan bahwa hasil analisis univariat komplikasi persalinan didominasi oleh pre eklampsi/eklampsi dan berkontribusi menyumbang risiko kematian ibu dengan OR sebesar 49,2 dan nilai $\mathrm{p}=0,027^{19}$

\section{Hambatan dan Masalah Rujukan}

Berdasarkan hasil wawancara, hambatan dan masalah rujukan pada ibu yang meninggal diantaranya keluarga terlambat merujuk ibu ke fasilitas kesehatan, jarak yang jauh dari fasilitas kesehatan, akses BPJS serta masalah transportasi yang lama menunggu.

Tingginya kematian ibu diantaranya akses jangkauan dalam mekanisme sistem rujukan, terutama pada akses BPJS saat dirujuk bidan dari rumah ke rumah sakit terlebih dahulu harus melalui rujukan puskesmas atau poned. Sehingga di puskesmas memperlambat waktu walaupun memperoleh pertolongan terlebih dahulu, padahal ibu dalam kondisi sudah gawat darurat, dan ketika tidak sanggup baru dirujuk kembali ke rumah sakit. Proses sistem rujukan yang bertingkat memperlambat waktu penanganan yang seharusnya dapat segera ditangani di fasilitas yang lengkap, sehingga tingginya angka kematian ibu sebagian besar terjadi akibat kegawatdaruratan yang dalam penanganannya perlu dilakukan segera secara obstetri, sedangkan akses pelayanan melalui rujukan seringkali terkendala determinan jarak/letak geografis yang jauh dari wilayah kerja, sehingga cenderung mengalami keterlambatan dalam penanganannya yang berdampak terhadap kematian. ${ }^{21}$

Sebenarnya sebagian besar kematian ibu masih dapat dicegah apabila dapat diberikan pertolongan pertama yang adekuat, yaitu melalui persalinan yang aman oleh tenaga kesehatan terlatih. Upaya penanganan kematian ibu yang dapat dikembangkan diantaranya bagi persalinan BPJS dengan kondisi gawat darurat medis, puskesmas segera melakukan mekanisme sistem rujukan secara langsung ke fasilitas rujukan seperti rumah sakit. Upaya pencegahan dalam menurunkan kematian diantaranya memberikan penyuluhan mengenai sistem rujukan, khususnya terhadap ibu hamil berisiko diberikan informasi persiapan persalinan secara intensif, agar dapat dapat mempersiapkan persalinan yang matang dengan memilih tujuan tempat persalinan sesuai kondisi risiko, sehingga keterlambatan dalam kegawat daruratan yag terkendala jarak dapat diantisipasi segera.

\section{Akses Pelayanan Kesehatan}

Berdasarkan akses pelayanan kesehatan jarak tempuh paling jauh $\pm 15 \mathrm{Km}$ dan paling dekat \pm 1 $\mathrm{Km}$, idealnya jangkauan masyarakat (jarak tempuh maupun waktu tempuh) terhadap sarana pelayanan kesehatan haruslah semudah mungkin sehingga memudahkan masyarakat untuk memperoleh pelayanan kesehatan. Letak geografis beberapa daerah di Kabupaten Majalengka memungkinkan 
tenaga kesehatan harus ekstra dalam merujuk ke fasilitas kesehatan terutama di daerah pegunungan. Menurut Thabrany et al, jarak ke pusat pelayanan dan waktu tempuh memiliki dampak signifikan dengan pemanfaatan pelayanan kesehatan. ${ }^{15}$ Dalam buku Modul Dasar Bidan di Masyarakat, dikatakan bahwa keterlambatan berarti kematian. Keterlambatan dapat terjadi dimana saja kapan saja dan keterlambatan dapat menyebabkan komplikasi yang serius yang dapat mengakibatkan kematian ibu. Indonesia sebagai negara berkembang dengan daerah yang luas, penduduk yang padat (tetapi distribusi tidak merata) masih sulit untuk mengatasi sistem rujukan ini terutama jarak perjalanan dan waktu tempuh. ${ }^{25}$

Berdasarkan segi dukungan dan kerja sama masyarakat, lebih dari setengahnya dukungan masyarakat maupun tokoh masyarakat besar, terutama dalam bentuk pengadaan ambulan desa, pengurusan BPJS sampai mengantar pasien ke rumah sakit. Artinya sudah ada kesadaran dan kepedulian masyarakat dalam hal mengupayakan kehamilan dan persalinan yang aman bagi ibu terutama dalam keadaan darurat dan perlu rujukan. Kerjasama yang baik antara masyarakat dan tenaga kesehatan akan membangun kepercayaan yang positif sehingga masyarakat akan mampu, peka dan mengenal serta memecahkan masalah kesehatannya dalam rangka meningkatkan mutu hidup dan kesejahteraan masyarakat.

\section{SIMPULAN DAN SARAN}

Berdasarkan analisa data dan pembahasan, maka dapat disimpulkan beberapa hal sebagai berikut:

1. Lebih dari setengahnya ibu meninggal periode nifas dengan penyebab tertinggi kematian ibu karena Hipertensi Dalam Kehamilan (HDK).

2. Faktor determinan jauh, lebih dari setengahnya pendidikan ibu SMP, sebagian besar tidak bekerja dan rata-rata pendapatan keluarga sesuai dengan UMK Kabupaten Majalengka

3. Faktor determinan antara, sebagian besar ibu tidak mengalami KEK dan anemia, usia ibu meninggal pada usia 20-35 tahun, lebih dari setengahnya terjadi pada primipara, jangkauan pelayanan kesehatan dari lama rujukan sampai tiba di pelayanan kesehatan ditempuh sekitar 1-2 jam dan hampir seluruh ibu melakukan pemeriksaan kehamilan sampai persalinan dengan tenaga kesehatan

4. Faktor determinan dekat yang berpengaruh terhadap kematian ibu adalah komplikasi pada kehamilan, persalinan dan nifas. Komplikasi yang paling banyak adalah disebabkan karena Hipertensi Dalam Kehamilan

5. Hambatan dan masalah rujukan pada ibu yang meninggal dikarenakan keluarga terlambat merujuk ibu ke fasilitas kesehatan, jarak yang jauh dari fasilitas kesehatan, akses BPJS serta masalah transportasi yang lama menunggu.

6. Akses pelayanan kesehatan jarak tempuh paling jauh $\pm 15 \mathrm{Km}$ dan paling dekat $\pm 1 \mathrm{Km}$

Kemudian tim peneliti memberikan saran sebagai berikut

1. Memastikan sistem rujukan dari rumah ke puskesmas dan ke rumah sakit berjalan optimal

2. Perlu adanya pemberdayaan masyarakat untuk menumbuhkan kesadaran, kemauan dan kemampuan serta menjadi penggerak dalam menurunkan AKI

3. Kecepatan dan ketepatan tenaga kesehatan (baik bidan maupun dokter) dalam mengambil keputusan, merujuk, melakukan penanganan tindakan kegawatdaruratan serta stabilisasi kondisi pasien merupakan faktor penting dalam menyelamatkan nyawa ibu, karena kematian ibu sering terjadi karena keterlambatan dalam penentuan diagnosa komplikasi, terlambat mengambil keputusan, terlambat merujuk dan terlambat ditangani.

\section{DAFTAR PUSTAKA}

1. Pamela C Banda. Status of Maternal Mortality in Zambia: Use of Routine Data. African Populasi Studi. 2015;29:No 2.

2. Asamoah et al. Distribution Of Causes Of Maternal Mortality Among Different Socio-Demographic Groups In Ghana; A Descriptive Study. BMC Public Health 2011;11:159. Available from: http://www.biomedcentral.com

3. WHO. Mother Days. Situasi kesehatan Ibu. Pusat Data dan Kementerian Kesehatan RI Jakarta: InfoDATIN; 2014.

4. National Geographic Indonesia. Indeks Pembangunan Indonesia Alami Kemajuan. 2016; Available from: http://nationalgeographic.co.id

5. Kemenkes RI. Profil Kesehatan Indonesia. Jakarta : Kemenkes RI. 2014;

6. Department of Reproductive Health and Research WHO. Trend in Maternal Mortality. International Statistical Classification of Deseases, Injuries and Causes of Death. 2010;Edition IC.

7. Unicef Indonesia. Ringkasan Kajian Kesehatan Ibu Dan Anak. 2012; Available from: www.unicef.org

8. Kemenkes RI. Profil Kesehatan Indonesia Tahun 2015. 2016; Available from: www.depkes.go.id

9. Yakoob MY et al. The effect Of Providing Skilled Birth Attendance And Emergency Obstetric Care In Preventing Stillbirths. BMC Public Health. 2011; Available from: http://www.biomedcentral.com/1471-2458/11/S3/S7.

10. Goldenberg, R.L. \& Mcclure EM. Maternal, Fetal And Neonatal Mortality: Lessons Learned From Historical Changes In High Income Countries And Their Potential Application To Low-Income Countries. Maternal Health Neonatol Perinatol. 2015;1(3), pp.1.

11. Graham. W.J.et al. Measuring Maternal Mortality: An Overview Of Opportunities And Options For Developing Countries. BMC Med. 2008;6, p.12.

12. Dinkes Prov. Jabar. Visualisasi Data Kesehatan Provinsi Jawa Barat. 2015; 
13. Dinkes Kab. Majalengka. Profil Kesehatan Kabupaten Majalengka. 2016;

14. Sarwani dan Nurlaela. Analisis Faktor Risiko Kematian Ibu (Studi Kasus di Kabupaten Banyumas). 2010; Available from: www.eprints.ums.ac.id.

15. Aeni N. Faktor Risiko Kematian Ibu di Kabupaten Pati. Kantor Penelitian \& Pengembangan Kabupaten Pati. J Kesehat Masy Nas [Internet]. 2011;7. Available from: www.eprints.ums.ac.id

16. Manuaba I. Ilmu Kebidanan, Penyakit Kandungan dan KB untuk Pendidikan Bidan. Jakarta: Jakarta: EGC.; 2012.

17. Sumarni. Faktor-Faktor Yang Mempengaruhi Kematian Ibu Di Kabupaten Banyumas Jawa Tengah Periode Tahun 2009-2011. J Ilm Kebidanan [Internet]. 2014;5 No 1:5262. Available from: portalgaruda.org

18. Pusat Data Dan Informasi Kementrian Kesehatan RI. Mother's Day. 2014; Available from: www.depkes.go.id

19. Febriana A. Faktor-Faktor Risiko Yang Mempengaruhi Kematian Maternal. Prodi Magister Epidemiologi Program Pasca Sarjana Undip. 2007;

20. Badan Pusat Statistik Kabupaten Majalengka. Kabupaten Majalengka Dalam Angka 2016 [Internet]. 2016. Available from: https://majalengkakab.bps.go.id

21. Surat Keputusan Gubernur dengan nomor 561/Kep. 1191Bangsos/2016 tertanggal 21 November 2016 tentang Upah Minimum Kabupaten/Kota di Jawa Barat Tahun 2017,. Jawa Barat; 2017.

22. Dinas Kesehatan Kabupaten Majalengka. Profil Kesehatan Tahun 2016. 2017;

23. Fibriani AI, Azam M. Three Delay Model Sebagai Salah Satu Determinan Kematian Ibu Di Kabupaten Cilacap. Jurnal Unnes [Internet]. 2012; Available from: http//journal.unnes.ac.id

24. Junaidi Iskandar. Hipertensi : Pengenalan, Pencegahan dan Pengobatan. BIP Jakarta; 2010.

25. Jennifer Uzan et al. Pre-eclampsia: Pathophysiology, Diagnosis, And Management. US National Library Medicine National Institutes Health. 2011;7:467-74.

26. WHO. Safe Motherhood Foundation Module: The Midwife In The Community Education Material For Teachers Of Midwifery. Jakarta: EGC; 1996.

\section{PROFIL PENULIS UTAMA}

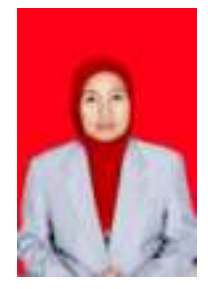

Penulis bernama lengkap Ruri Yuni Astari, S.Si.T., M.Keb. Lahir di Purworejo, 29 Juni 1978. Keseharian sebagai Dosen di STIKes YPIB Majalengka. Jika ada saran dan masukan terkait paper ini bisa emailkan ke: ruriastari78@gmail.com. 